\title{
Larval ecology of a suite of snappers (family: Lutjanidae) in the Straits of Florida, western Atlantic Ocean
}

\author{
E. K. D'Alessandro ${ }^{1, *}$, S. Sponaugle ${ }^{1}$, J. E. Serafy ${ }^{1,2}$ \\ ${ }^{1}$ Division of Marine Biology and Fisheries, Rosenstiel School of Marine and Atmospheric Science, University of Miami, \\ 4600 Rickenbacker Causeway, Miami, Florida 33149, USA \\ ${ }^{2}$ National Marine Fisheries Service, Southeast Fisheries Science Center, 75 Virginia Beach Drive, Miami, Florida 33149, USA
}

\begin{abstract}
Despite the ecological and economic importance of western Atlantic Ocean lutjanid species, little is known about their larval stage. Pelagic larval distribution, abundance, growth, mortality, and spawning patterns of 6 western Atlantic snapper species were examined from ichthyoplankton samples collected monthly over $2 \mathrm{yr}$ along a transect spanning the east-west axis of the Straits of Florida (SOF). Successful spawning occurred primarily from July to September when water temperatures were warmest and larvae were most abundant in the upper $50 \mathrm{~m}$ towards the east or west sides of the SOF. Species-specific variability in spatiotemporal larval patterns tracked adult life history characters. Larvae of species associated with shallow coral reefs were spawned in the waning half of the lunar cycle (third quarter to new moon), were most abundant in the 0 to $25 \mathrm{~m}$ depth range, and where cross-SOF distributions were not uniform, were distributed mainly towards the eastern SOF. Larvae of deeper-dwelling species exhibited lower mortality and no lunar pattern in spawning (Etelis oculatus only), were distributed deeper in the water column and occurred progressively deeper with ontogeny, and where cross-SOF distributions were not uniform, were most abundant in the western SOF. Despite species-specific variability in spatial distributions and equivalent east-west mortality rates, at least one measure of larval growth in 4 of 6 species of snapper revealed significantly faster growth in the western versus the eastern SOF, which may be related to higher prey availability in the west. Results of this study provide insight into the pelagic phase of 6 important snapper species, with implications for understanding adult populations.
\end{abstract}

KEY WORDS: Snapper larvae $\cdot$ Larval growth $\cdot$ Larval mortality $\cdot$ Larval distribution

\section{INTRODUCTION}

The 106 species of snapper (family Lutjanidae) are economically important demersal predators found worldwide in tropical and subtropical waters (Nelson 2006, Moura \& Lindeman 2007). Inhabiting diverse ecosystems ranging from shallow mangrove/seagrass systems and coral reefs to deep shelf edges, snappers are targets of subsistence, commercial, and recreational fisheries around the globe. The 18 lutjanid species that occur in the western central North Atlantic Ocean (bounded by $35^{\circ} \mathrm{N}$ latitude, the equator and $40^{\circ} \mathrm{W}$ longitude) are among the most economically important fishes in the region and are members of 6 genera divided among 3 subfamilies: Lutjaninae (Lutjanus, Ocyurus and Rhomboplites), Etelinae (Pristipomoides and Etelis) and Apsilinae (Apsilus) (Lindeman et al. 2006). The 11 species in the genus Lutjanus and 1 species in the genus Ocyurus encompass all of the lutjanids that, as adults, inhabit nearshore coral reefs and shallow backreef habitats. The 3 species in the genus Pristipomoides and 1 species in each of the genera Apsilus, Etelis, and Rhomboplites are all found as adults in deeper shelf waters, usually well below $50 \mathrm{~m}$. 
Lutjanids, like most marine fishes, have a pelagic egg/larval stage that lasts for several weeks during which time they are highly vulnerable to starvation, predation, and advection away from suitable juvenile habitat, and survival rates may be near zero (Houde 1987). Although adults undertake spawning migrations and ontogenetic movements of juveniles connect nearshore habitats, the primary process determining connectivity between fragmented adult populations is believed to be dispersal of the pelagic larval stage (Pineda et al. 2007, Cowen \& Sponaugle 2009). Larval dispersal may be influenced by a variety of factors in the pelagic environment (e.g. currents, larval behavior, vertical distribution, growth and mortality). Understanding the effects of these factors is critical in light of the importance of connectivity for establishing and implementing spatially based fishery management (Fogarty \& Botsford 2007).

Despite their economic importance, little is known about the early life history (ELH) of lutjanids. Complete descriptions of larval ontogeny are available for only 6 of the 18 western Atlantic snapper species, and the few studies on lutjanid larvae have been descriptive in nature and/or used captive-bred larvae (Riley et al. 1995, Clarke et al. 1997, Drass et al. 2000), or have examined otolith-based traits of late-stage larvae and juveniles to make inferences about pelagic larval life (Tzeng et al. 2003, Denit \& Sponaugle 2004). Studies directly examining the ELH of wild-caught larvae beyond coarse distributions at the genus level are largely lacking (but see Powles 1977, Houde et al.
1979, Comyns et al. 2003), due in large part to the difficulties involved in adequately sampling diffuse populations of larvae in the open ocean, and in identifying them to the species level (Leis 1987, Lindeman et al. 2006). A recent 2 yr study collected monthly plankton samples across the Straits of Florida (SOF) and revealed consistent spatiotemporal patterns in abundance, distribution, and growth of the larvae of several fish taxa; most notably higher larval growth on the western side of the SOF (Llopiz \& Cowen 2009, Sponaugle et al. 2009, 2010, Richardson et al. 2010). Using these same samples, the objectives of this study were to (1) test for species-specific spatiotemporal patterns in snapper larval abundance and distribution, (2) estimate both seasonal and within-month (lunar) patterns of spawning, and (3) quantify larval growth and mortality and test whether these differed between the eastern and western sides of the SOF.

\section{MATERIALS AND METHODS}

Sample collection. Plankton samples were collected during daylight hours from January 2003 through December 2004 on 24 monthly cruises at 17 fixed stations along a transect in the $\mathrm{SOF}$, from the east Florida shelf to the Great Bahama Bank (25.5 $\mathrm{N}$; Fig. 1). Current flow in this area is dominated by the Florida Current (FC, a major western boundary current flowing north through the SOF at speeds of up to $2 \mathrm{~m} \mathrm{~s}^{-1}$. Coastal upwelling and passage of numerous mesoscale and sub-
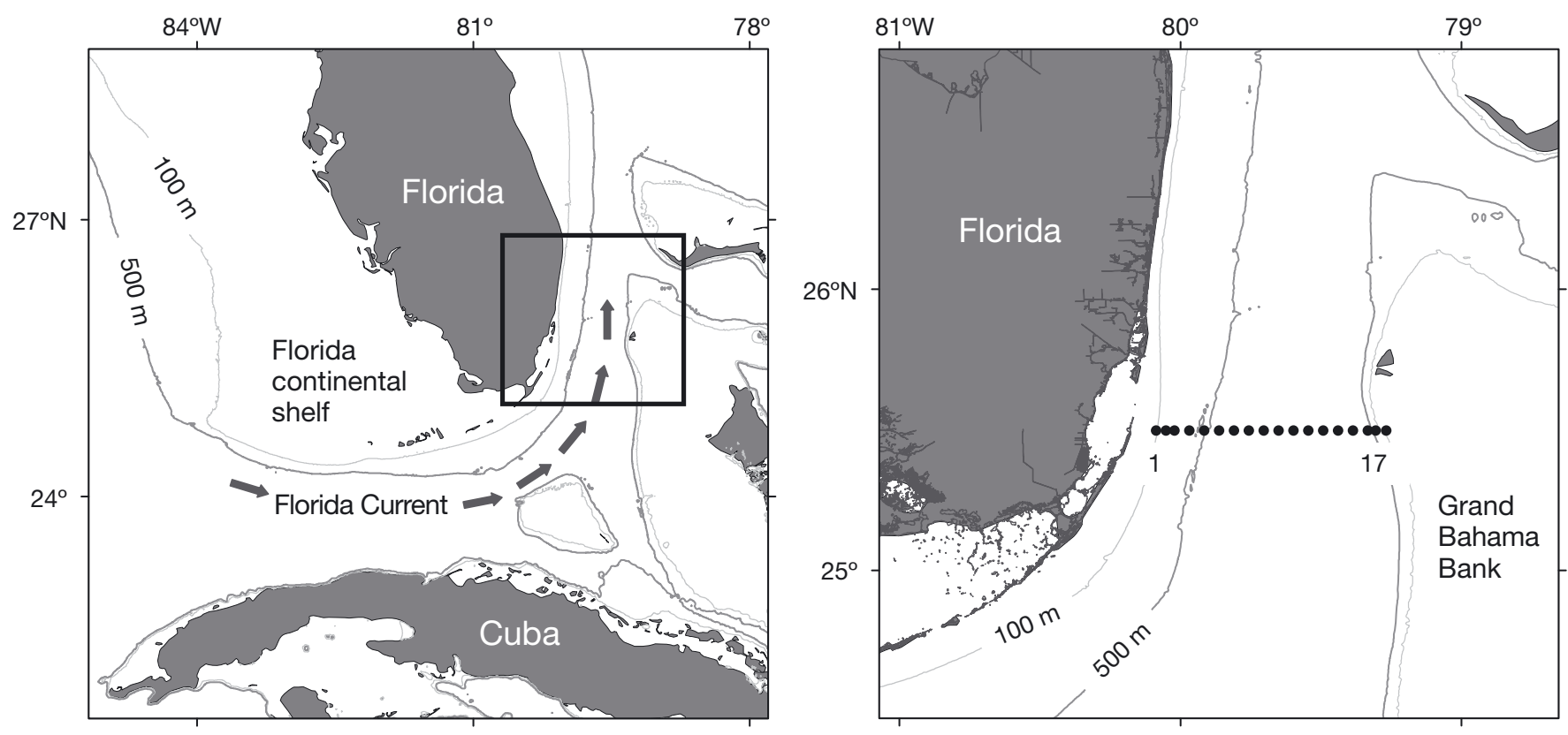

Fig. 1. Study area. (•) The 17 stations across the Straits of Florida, sampled monthly from 2003 to 2004 
mesoscale eddies make the western SOF adjacent to the Florida Keys (FK) higher in primary production than in the eastern portion (Hitchcock et al. 2005). Stations were at least $2 \mathrm{~km}$ apart, spaced closer together at the extremes of the transect and considered independent of each other. Inclement weather prevented complete sampling of this transect in December 2003 and January and November 2004. A shipboard acoustic Doppler current profiler (ADCP) recorded vertically discrete current speeds to $100 \mathrm{~m}$ depth, while a multiple opening-closing net and environmental sampling system (MOCNESS) was used make oblique tows of $25 \mathrm{~m}$ depth bins from the surface to $100 \mathrm{~m}$, and a neuston net sampled the top $\sim 0.5 \mathrm{~m}$ of the water column. Both of these nets were towed at a speed of $1 \mathrm{~m} \mathrm{~s}^{-1}$ and were outfitted with continuously recording flow meters and depth and temperature sensors, and contained dual openings with $1 \mathrm{~mm}$ and $150 \mu \mathrm{m}$ mesh nets (MOCNESS: $4 \mathrm{~m}^{2}$ with $1 \mathrm{~mm}$ mesh and $1 \mathrm{~m}^{2}$ with $150 \mu \mathrm{m}$ mesh [Guigand et al. 2005]; Neuston: $2 \mathrm{~m}^{2}$ with $1 \mathrm{~mm}$ mesh and $0.5 \mathrm{~m}^{2}$ with $150 \mu \mathrm{m}$ mesh). Samples from the $150 \mu \mathrm{m}$ mesh nets were not used in this study. Upon collection, samples were immediately fixed in 95\% ethanol (EtOH) and later sorted to remove all fish larvae. All lutjanid larvae were staged as preflexion (posterior notochord in line with the plane of the body), flexion (posterior notochord turned upward but caudal peduncle not yet fully developed), or postflexion (caudal peduncle fully developed) and their notochord lengths (NL; preflexion larvae) or standard lengths (SL; postflexion larvae) were measured to the nearest $0.1 \mathrm{~mm}$. Rhomboplites aurorubens and lutjanids in the subfamily Etelinae were identified to the species level with a standard fish larvae guide (Lindeman et al. 2006), and larvae in the genera Lutjanus and Ocyurus were identified by means of molecular techniques.

Molecular identification of snapper larvae. Isolation and purification of DNA, PCR, PCR purification, sequencing reaction, and sequence purification from snapper larvae in the genera Lutjanus and Ocyurus followed methods described by Richardson et al. (2007) using the Genfind kit (Agencourt) for DNA isolation and an Evolution P3 liquid-handling robot (Perkins Elmer) to minimize pipetting time and error. Primers used in the amplification of a $655 \mathrm{bp}$ region of the cytochrome $c$ oxidase I (COI) gene were: FishF1, FishF2, FishR1, FishR2 (Ward et al. 2005) and an additional 2 snapper-specific primers designed for this study (FishF3: TTT GAG ACG ACC AGA TTT AT; FishR3: GAT TAG GAC GGC TCA RAC GAA). Combinations of these 3 forward and 3 reverse primers yielded a 366-655 bp region of the COI gene. Sequences with trace scores $<30$ and read lengths < 100 were discarded and the entire molecular identification protocol was rerun on the corresponding larva.
If 2 runs of this protocol failed to produce a sequence with an adequate trace score and read length, the specimen was not identified. Sequences that passed these criteria were entered into the identification engine of the Barcode of Life Data System (BOLD), producing both a neighbor-joining tree highlighting the location of the unknown sequence, as well as a list of the 100 closest reference sequence matches (Ratnasingham \& Hebert 2007). If results were ambiguous or if the sequence was grouped at an equal distance with 2 or more species, the sequence was discarded and the specimen was rerun or left unidentified.

Abundance and distribution. To test for patterns in abundance across the SOF, the 8 most abundant snapper species were examined, and Stns 1 to 9 and 10 to 17 were grouped into western and eastern stations, respectively. Depth patterns were computed by converting larval catches to abundance by multiplying the density (no. larvae $\mathrm{m}^{-3}$ ) of each oblique net tow by the vertical distance it covered, yielding the number of larvae under $1 \mathrm{~m}^{2}$ of sea surface within a given depth bin. To examine seasonal and cross-SOF patterns, abundance was summed across depth bins to give the number of larvae under $1 \mathrm{~m}^{2}$ of sea surface. It has been suggested that this measure of abundance more accurately reflects changes in abundance than mean density when larvae are not distributed equally throughout the water column (Lyczkowski-Shultz \& Steen 1991, Comyns et al. 2003). Abundances were summed across stations (after being weighted to correct for unequal distances between sampling stations) to test for temporal (monthly) patterns, and across time (all 24 cruises over the 2 yr) to identify spatial patterns. Total abundance from all stations and all cruises was separated into $1 \mathrm{~mm}$ SL size classes to construct lengthfrequency plots. The spatiotemporal abundance patterns of the 8 most abundant taxa overall were individually examined. The low sample size of the remaining species (including unidentified larvae) prevented meaningful analysis. Even in the 8 most abundant taxa, however, the abundance of zero values prevented standard statistical analyses of species-specific abundances; thus, we applied the delta approach sensu Serafy et al. (2007). Specifically, we analyzed patterns in larval frequency of occurrence (proportion positive) and larval concentration (density when present, ignoring zero values) separately. Species-specific patterns in frequency of occurrence were examined by month with Rayleigh tests (Zar 1999), and by depth and station with chi-square tests under the null hypothesis of uniform distributions. When the Rayleigh test indicated a significant difference in monthly patterns of occurrence, the mean month around which the data were distributed was calculated. Patterns in concentration were examined by month, again with 
Rayleigh tests, and by depth and station with KruskalWallis tests (due to failure of these data to meet assumptions of parametric statistics).

Ontogenetic differences in vertical distributions of snapper larvae were investigated by using stage-specific centers of mass $\left(z_{\mathrm{cm}}\right)$ of the 8 most abundant taxa at each station as the statistical unit. Center of mass was calculated at each station as the mean depth that each net sampled and weighted by the proportion of the larvae sampled at that station captured in those nets:

$$
z_{\mathrm{cm}}=\sum_{i} \frac{a_{i}}{\sum a_{i}} z_{i}
$$

where $z_{i}$ is the mean of the depth range sampled by net $i$ (based on volume sampled at each depth within the depth range) and $a_{i}$ is the abundance of larvae in net $i$. A mean center of mass and SE was then calculated for each stage within a taxon and statistical differences were determined with Kruskal-Wallis tests.

Otolith analysis. Six species were selected for otolith analysis (Table 1) based on sample size, economic relevance and cross-SOF distributions. Individual larvae were randomly selected from all peak spawning months, from eastern and western regions and from $1 \mathrm{~mm}$ SL size bins to encompass the complete length distribution and spawning season in approximately even sample sizes from each portion of the SOF. One sagittal otolith was randomly selected per sampled individual and embedded in crystal-bond thermoplastic glue on a glass microscope slide. A transverse section of each otolith was obtained by polishing (P2000 silicon-carbide abrasive paper, Nihonkenshi) each side of the otolith to the core. A digital image of each section was taken at $1000 \times$ with a DMLB microscope (Leica) equipped with a MTI video camera and frame-grabber (Dage). Image Pro Plus 4.5 software (Media Cybernetics) was used for image analysis, and increments were measured and enumerated along the broader and more rounded of the 2 longest axes from the otolith's core to its outer edge. This process was repeated twice for each otolith by the same reader, and if counts differed by $\leq 5 \%$, one count was randomly selected for analysis. If replicate counts differed by $>5 \%$, the otolith was read a third time. If this third read differed by $\leq 5 \%$ from one of the other 2 reads, one of these was randomly chosen for analysis. Otherwise, the otolith was excluded from further analysis (Sponaugle 2009).

Daily otolith increment formation has been validated in Lutjanus griseus, L. synagris, L. apodus and Ocyurus chrysurus (Lindeman 1997, Allman 1999, Ahrenholz 2000, Allman \& Grimes 2002, Mikulas \& Rooker 2008) and was assumed in L. analis and Etelis oculatus. Overall similarity in increment widths and appearance between these species and those that have been validated were consistent with this assumption. The number of otolith increments plus a 2 d correction for the delay between hatching and exogenous feeding/increment formation (Lindeman 1997) provided posthatch larval age in days, while the distance between each pair of increments provided a measure of daily growth

Table 1. Taxon-specific adult depth ranges (ADR); sample sizes; standard length (SL) ranges - overall, and at preflexion (PRF), at flexion (F) and postflexion (PTF); and otolith sample sizes (D: otoliths discarded; R: otoliths retained) for lutjanid larvae caught in the Straits of Florida from 2003 to 2004. Taxa are ordered by sample size. SCR indicates that a specific depth range was not available but the species is commonly associated with shallow coral reefs. Bold: species for which otolith-based age and growth analyses were conducted. na: not available

\begin{tabular}{|c|c|c|c|c|c|c|c|c|}
\hline \multirow[t]{2}{*}{ Taxon } & \multirow{2}{*}{$\begin{array}{c}\text { ADR } \\
(\mathrm{m})\end{array}$} & \multirow[t]{2}{*}{$\mathrm{n}$} & \multicolumn{4}{|c|}{ SL ranges $(\mathrm{mm})$} & \multicolumn{2}{|c|}{ Otoliths } \\
\hline & & & Overall & PRF & F & PTF & $\mathrm{D}$ & $\mathrm{R}$ \\
\hline Rhomboplites aurorubens & $25-?$ & 275 & $2.9-12.2$ & $2.9-4.7$ & $4.0-6.2$ & $5.8-12.2$ & 0 & 0 \\
\hline Pristipomoides spp. & $24-488$ & 250 & $3.4-24.0$ & $3.4-4.4$ & $4.1-5.8$ & $5.4-24.0$ & 0 & 0 \\
\hline Lutjanus apodus & $0-50$ & 196 & $3.1-9.4$ & $3.1-4.8$ & $4.4-6.3$ & $6.3-9.4$ & 8 & 75 \\
\hline L. synagris & $0-400$ & 153 & $2.8-8.9$ & $2.8-4.6$ & $3.9-5.7$ & $5.6-8.9$ & 10 & 45 \\
\hline Etelis oculatus & $135-450$ & 126 & $3.2-15.7$ & $3.2-4.3$ & $4.3-7.1$ & $5.0-15.7$ & 6 & 69 \\
\hline Ocyurus chrysurus & $1-165$ & 118 & $2.9-9.0$ & $2.9-4.6$ & $4.3-7.1$ & $7.5-9.0$ & 8 & 58 \\
\hline L. analis & $0-80$ & 114 & $2.7-8.8$ & $2.7-4.3$ & $4.1-6.3$ & $6.8-8.8$ & 8 & 44 \\
\hline L. griseus & $0-180$ & 95 & $2.7-9.5$ & $2.7-4.4$ & $4.3-7.0$ & $6.6-9.5$ & 10 & 54 \\
\hline L. jocu & $\mathrm{SCR}$ & 55 & $3.0-7.7$ & $3.0-4.4$ & $4.5-6.0$ & $5.7-7.7$ & 0 & 0 \\
\hline Lutjanus spp. & na & 55 & $2.8-8.8$ & $2.8-4.7$ & $4.4-6.7$ & $4.3-8.8$ & 0 & 0 \\
\hline L. buccanella & $60-230$ & 18 & $3.0-7.2$ & $3.0-4.5$ & $4.8-6.6$ & $6.1-7.2$ & 0 & 0 \\
\hline L. mahogoni & SCR & 18 & $3.4-7.2$ & $3.4-4.2$ & $4.3-6.0$ & $5.5-7.2$ & 0 & 0 \\
\hline L. cyanopterus & $0-40$ & 13 & $3.9-5.7$ & $3.9-4.9$ & $4.4-5.4$ & 5.7 & 0 & 0 \\
\hline L. vivanus & $90-240$ & 12 & $3.3-8.3$ & $3.3-3.8$ & $4.8-5.8$ & $5.6-8.3$ & 0 & 0 \\
\hline L. campechanus & $10-190$ & 2 & $3.7-4.2$ & na & na & na & 0 & 0 \\
\hline Total & & 1500 & $2.7-24.0$ & $2.7-4.9$ & $3.9-7.1$ & $4.3-24.0$ & 50 & 345 \\
\hline
\end{tabular}


for each larva. Because eggs of several western Atlantic snapper species are known to hatch within $24 \mathrm{~h}$ of fertilization in 27 to $28^{\circ} \mathrm{C}$ seawater (e.g. Watanabe et al. 1998, Turano et al. 2000), an additional day was added to posthatch age to obtain an estimate of the spawning/fertilization day. To ensure that otolith deposition rates could be used as a proxy for somatic larval growth, standard least-squares regressions were performed for each species analyzed between SL and otolith radius as well as between residuals of an otolith radius-at-age regression and residuals of a SL-at-age regression (Hare \& Cowen 1995).

Otolith-based growth comparisons. Initial analyses were performed to determine whether larval growth differed between sampling depths for each species. Larval growth (mean width of increments 1 to 5, increments 5 to 10 , and increments 10 to 15) was unrelated to depth of collection (ANOVA: p > 0.05); thus, larvae were pooled across depth bins for further analysis. Differences in daily growth and SL-at-age of snapper larvae between the eastern and western sides of the SOF were evaluated by using individual otolith increment widths and otolith radii, respectively, at Days 10 and 13 posthatch. Statistical significance in these patterns was evaluated by means of standard analysis of covariance (ANCOVA) with temperature included in the model to account for its effect on growth. The strong unidirectional nature of the $\mathrm{FC}$ results in larvae of different ages captured along the transect at the same time potentially having different origins and early growth environments (older larvae may have originated farther upstream). To minimize this potentially confounding effect, a mean of the $3 \mathrm{~d}$ of growth before capture was calculated for each larva (excluding the marginal increment) and these data were tested for differences between eastern and western stations by means of ANCOVA with water temperature and larval age included as covariates to account for their effect on larval growth (Sponaugle et al. 2010).

Overall larval growth of the analyzed species was modeled with length-at-age data and the Laird-Gompertz growth equation (Nielsen \& Munk 2004):

$$
L_{t}=L_{0} \times \mathrm{e}\left(g_{0} / \alpha\right) \times\left(1-\mathrm{e}^{-\alpha t}\right)
$$

where $L_{t}$ is length at time $t_{1} L_{0}$ is length at hatching, $g_{0}$ is specific growth rate at hatch, and $\alpha$ is the rate of exponential decay of the specific growth rate. Due to a lack of newly hatched (age $0 \mathrm{~d}$ ) and very young larvae (ages 1 to $7 \mathrm{~d}$ ) in the samples, size-at-age data were not used to calculate $L_{0}$. As described by Serafy et al. (2003), available species-specific mean size-at-hatch data from the literature were used to force the $y$-intercept through realistic values. For 3 species where no data were available, the mean of the values for those species with known lengths at hatch were used.
Separate growth models for the east and west sides of the SOF were created with a truncated age range such that both regions had representative data points throughout. These models were then tested with a likelihood ratio test (Kimura 1980) to determine whether model fit was significantly improved by the addition of an east-west division of the sampling stations. If no significant difference was detected, the pooled model was reported and used in subsequent analyses. Also, the instantaneous growth rates, $K$, from a simple exponential growth model $\left(L_{t}=L_{0} \mathrm{e}^{K X_{t}}\right)$ were calculated to simplify comparison between species and with other studies.

Mortality. With the Laird-Gompertz models and SL data, an age was assigned to every snapper larva of the analyzed species. An apparent mortality rate, $Z$, was then determined from age-specific abundance data by fitting a line of the form:

$$
\ln N_{t}=\ln N_{0}-Z(t)
$$

where $N_{t}$ is the abundance of larvae at time $t, N_{0}$ is the abundance of larvae at hatching, and the slope of the line, $Z$, is the apparent mortality rate (Houde et al. 1979). Because very young and old larvae were not sampled efficiently by the gear, the age range was truncated to minimize these biases (Richardson et al. 2009; Etelis oculatus: 20 to 35 d; all others: 16 to 24 d). In addition, because larvae may be distributed differently in the vertically stratified flow of the FC with ontogeny, larval abundances were weighted by the mean current flow within depth bins before pooling abundances vertically.

Mortality rates were tested for differences between east-west portions of the SOF using homogeneity of slope tests and were pooled across regions where no differences were found. Although mortality rates may have varied in time during this study, sampling was out of phase with larval production cycles and data were pooled over the entire study to satisfy the assumption of constant production (Morse 1989).

Spawning. To examine the timing of spawning relative to the lunar cycle, the lunar day on which each larva was spawned was obtained by first assigning a lunar day to each calendar day in 2003 and 2004 (new moon =1, full moon =15) and subtracting the postfertilization/spawning age from the capture date. For consistency with mortality calculations, a truncated age range was used, and larval abundances were weighted by mortality rates and sampling effort across the lunar cycle to yield relative spawning output. These data were then collapsed into a single lunar cycle. If the resulting lunar distribution was found to be significantly different from random by using a Rayleigh test (Zar 1999), then the mean lunar day around which the data were distributed was calculated. 

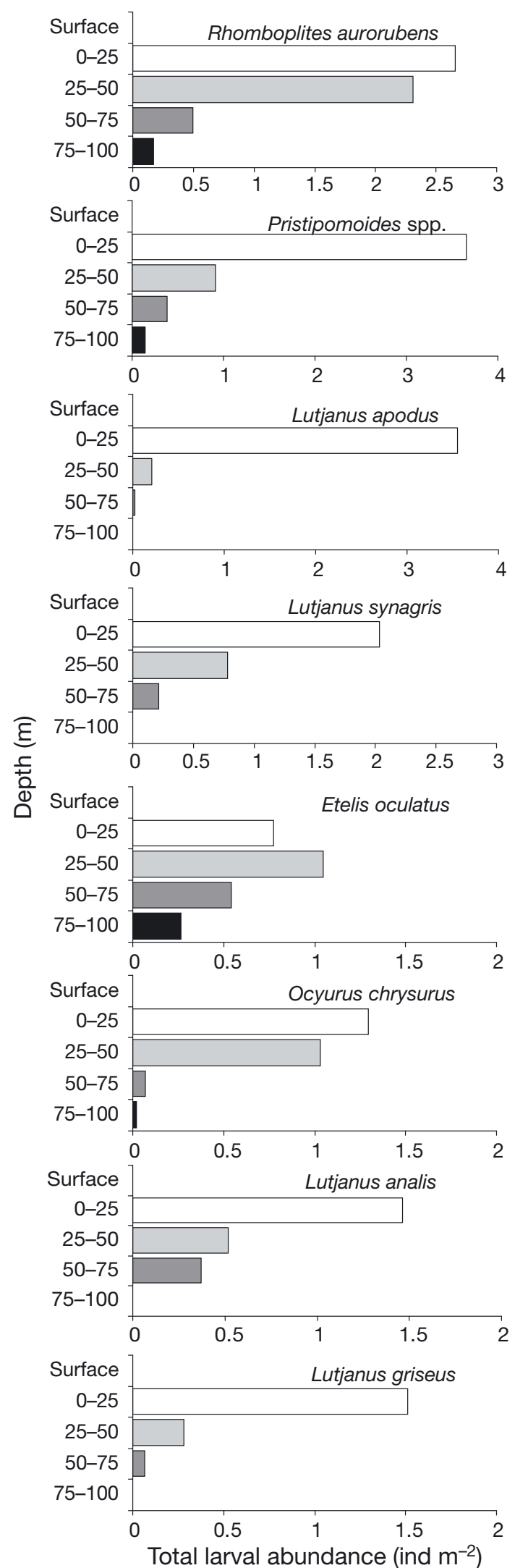
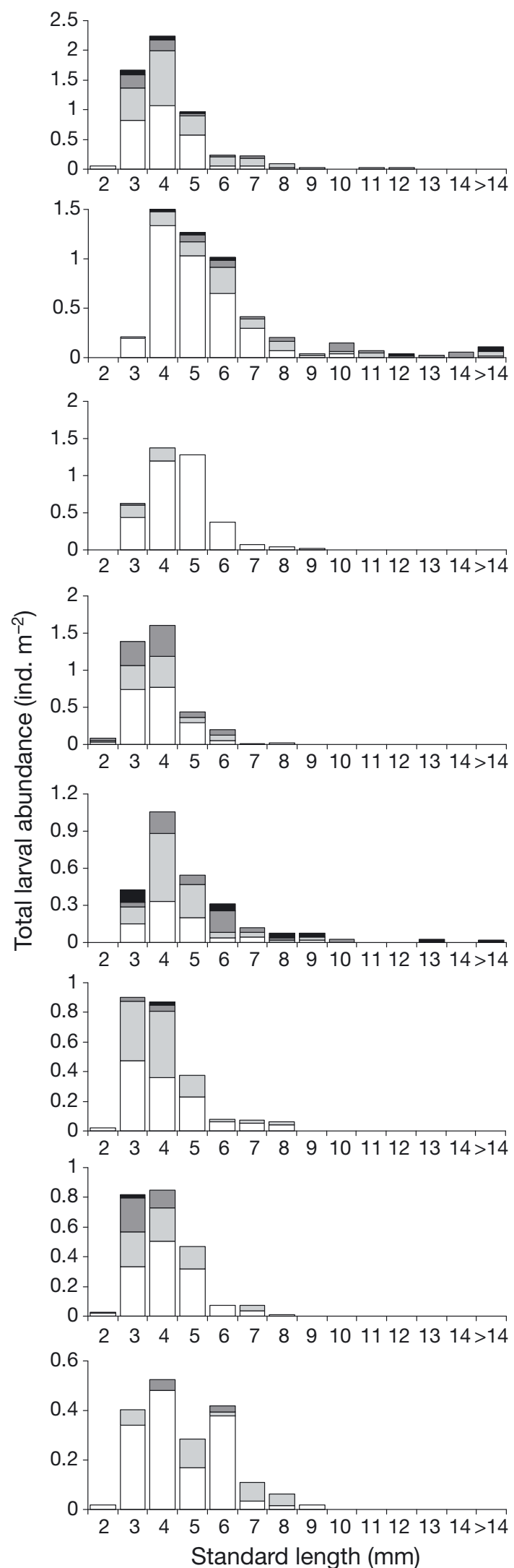

Fig. 2. Depth distributions (left panels) and length frequency distributions (right panels) of the larvae of the 8 most abundant lutjanid species captured in the Straits of Florida, expressed as total abundance summed across all stations and months. Shading in right panels corresponds to depth bins in left panels 


\section{RESULTS}

\section{Species and size distributions}

In total, 1500 snapper larvae ranging from 2.7 to $24.0 \mathrm{~mm}$ SL were collected during the 2 yr study, representing at least 14 of the 18 species known to occur in the western Atlantic Ocean and Caribbean Sea (Table 1). Of these, 96.3\% were identified to species level, leaving only 55 larvae unidentified. Larvae in the genus Pristipomoides could not be identified to species level because the COI regions of the mitochondrial DNA of 2 of the 3 western Atlantic species in this genus have not been sequenced, nor have their larval stages been adequately described. Of the identified larvae, 651 were identified morphologically as Rhomboplites aurorubens, Pristipomoides spp. or Etelis oculatus, while the remaining 794 were identified molecularly. Catches were dominated by the deeper-dwelling taxa $R$. aurorubens and Pristipomoides spp., which accounted for $35 \%$ of the total catch. The most abundant snapper larvae associated with shallow water coral reefs were Lutjanus apodus and L. synagris, which together accounted for $23 \%$ of the total catch. The 8 most abundant species that were further analyzed included 3 deeper dwelling species (i.e. do not occur shallower than $20 \mathrm{~m} ; R$. aurorubens, Pristipomoides spp. and E. oculatus), 2 species associated with shallow water coral reefs (i.e. do not occur deeper than $80 \mathrm{~m}_{i} L$. apodus, L. analis) and 3 species that occupy both shallow and deep habitats (L. synagris, Ocyurus chrysurus and L. griseus; Anderson 2002, Lindeman et al. 2006; Table 1). For all species, flexion commenced between 4 and $5 \mathrm{~mm}$ SL and the caudal peduncle was fully developed by 5 to $7 \mathrm{~mm}$ SL (Table 1). Lengthfrequency distributions revealed that very few larvae $<3$ to $4 \mathrm{~mm}$ SL or $>8$ to $9 \mathrm{~mm}$ SL were captured. The only larger larvae captured were of the deeper-dwelling taxa $R$. aurorubens, Pristipomoides spp. and E. oculatus (Table 1, Fig. 2).

\section{Temporal patterns}

Although snapper larvae were captured in 23 of 24 mo sampled, significant temporal patterns were identified in the frequency of occurrence (hereafter referred to as 'occurrence') and concentration (density when present) of the 8 most abundant species (Table 2). Peaks in both of these metrics as well as total cross-SOF abundance occurred from July through September when mean water temperatures in the upper $50 \mathrm{~m}$ of the water column across the SOF were $\geq 28^{\circ} \mathrm{C}$ (Fig. 3). Temporal distributions of all other lutjanids (not shown) also followed these general patterns. The only exception was Etelis oculatus, whose occurrence peaked in late September, but whose concentrations peaked in April (Table 2). Peak abundances of Pristipomoides spp. and Lutjanus analis were more than 3 times greater in 2003 than in 2004 while $L$. griseus and L. apodus displayed the opposite trend (Fig. 3). Abundances of Rhomboplites aurorubens, L. synagris, E. oculatus, and Ocyurus chrysurus were relatively consistent between years.

Among the 6 species for which the timing of spawning was back-calculated, a common pattern of lunar periodicity was evident in plots of total larval abundance versus lunar spawning day. Of the 6 species examined 4 displayed significant peaks in backcalculated spawning around the third quarter moon (Lunar Days 19.2 to 22.4; Fig. 4). Only Lutjanus griseus exhibited a significantly different lunar pattern, peaking just after the new moon (Lunar Day 1.6), and Etelis oculatus lacked any significant lunar pattern (Fig. 4).

Table 2. p-values from tests for significant patterns in temporal (monthly) occurrence (O) and concentration (C) distributions (Rayleigh tests), vertical and cross-strait (Straits of Florida, SOF) O distributions (chi-square tests), and cross-SOF C distributions (Mann-Whitney tests) of the 8 most abundant larval snapper species (shown in order of abundance). Where monthly distributions were significantly nonuniform, the mean month about which the data were distributed is given in parentheses (i.e. 1 for January up to 12 for December). Where cross-SOF distributions were found to be significantly different from uniform, the direction of this difference is given in parentheses. W: west; E: east

\begin{tabular}{|c|c|c|c|c|c|c|}
\hline \multirow[t]{2}{*}{ Taxon } & \multicolumn{2}{|c|}{ Temporal } & \multicolumn{2}{|c|}{ Vertical } & \multicolumn{2}{|c|}{ Cross-SOF } \\
\hline & $\mathrm{O}$ & $\mathrm{C}$ & $\mathrm{O}$ & $\mathrm{C}$ & $\mathrm{O}$ & $\mathrm{C}$ \\
\hline Rhomboplites aurorubens & $<0.001(8.3)$ & $<0.001(7.6)$ & $<0.001$ & 0.752 & $<0.001(\mathrm{~W}>\mathrm{E})$ & 0.189 \\
\hline Pristipomoides spp. & $<\mathbf{0 . 0 0 1}(8.8)$ & $<\mathbf{0 . 0 0 1}(8.6)$ & $<0.001$ & 0.638 & $<0.001(\mathrm{~W}>\mathrm{E})$ & 0.342 \\
\hline Lutjanus apodus & $<\mathbf{0 . 0 0 1}(8.8)$ & $<\mathbf{0 . 0 0 1}(7.5)$ & $<0.001$ & 0.541 & $\mathbf{0 . 0 3 0}(\mathrm{W}<\mathrm{E})$ & 0.749 \\
\hline L. synagris & $<\mathbf{0 . 0 0 1}(7.5)$ & $<\mathbf{0 . 0 0 1}(6.5)$ & $<0.001$ & 0.850 & $0.050(\mathrm{~W}>\mathrm{E})$ & 0.064 \\
\hline Etelis oculatus & $<\mathbf{0 . 0 0 1}(9.7)$ & $<\mathbf{0 . 0 0 1}(4.3)$ & $<0.001$ & 0.026 & $0.864(\mathrm{~W}=\mathrm{E})$ & 0.570 \\
\hline Ocyurus chrysurus & $<\mathbf{0 . 0 0 1}(8.5)$ & $<\mathbf{0 . 0 0 1}(6.6)$ & $<0.001$ & 0.916 & $0.751(\mathrm{~W}=\mathrm{E})$ & 0.487 \\
\hline L. analis & $<0.001(8.6)$ & $<0.001(7.6)$ & $<0.001$ & 0.199 & $0.172(\mathrm{~W}=\mathrm{E})$ & $<0.001(\mathrm{~W}<\mathrm{E})$ \\
\hline L. griseus & $<0.001(9.0)$ & $<\mathbf{0 . 0 0 1}(9.3)$ & $<0.001$ & 0.355 & $0.251(\mathrm{~W}=\mathrm{E})$ & 0.379 \\
\hline
\end{tabular}




\section{Spatial patterns}

Neuston net catches were not directly comparable with MOCNESS nets due to differences in sizes of the net openings and tow trajectories (oblique in MOC-
NESS nets and level in neuston nets). However, only 9 ( $0.6 \%$ of the total catch) snapper larvae were captured in neuston nets during the entire study despite the disproportionately large amount of time these nets sampled the top $0.5 \mathrm{~m}$ of the water column. Occurrences of

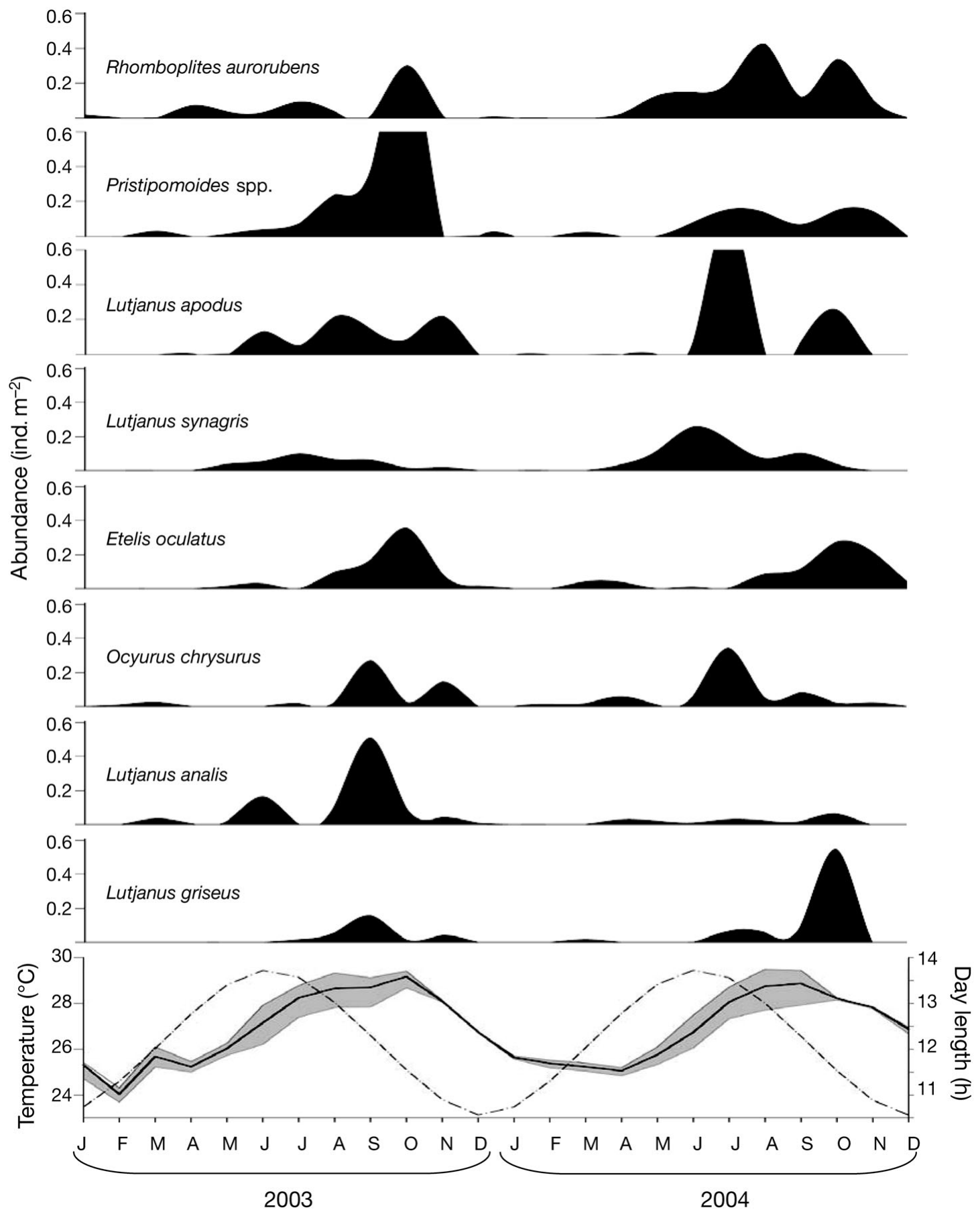

Fig. 3. Spline-smoothed total larval abundance (dark area) over time for the 8 most abundant snapper species captured during the 2 yr study (top 8 panels, shown in order of abundance). Bottom panel-solid line and shaded area: mean water temperature and temperature range, respectively, across the Straits of Florida in the upper $50 \mathrm{~m}$ of the water column; dashed line: day length across the sampling transect over time 

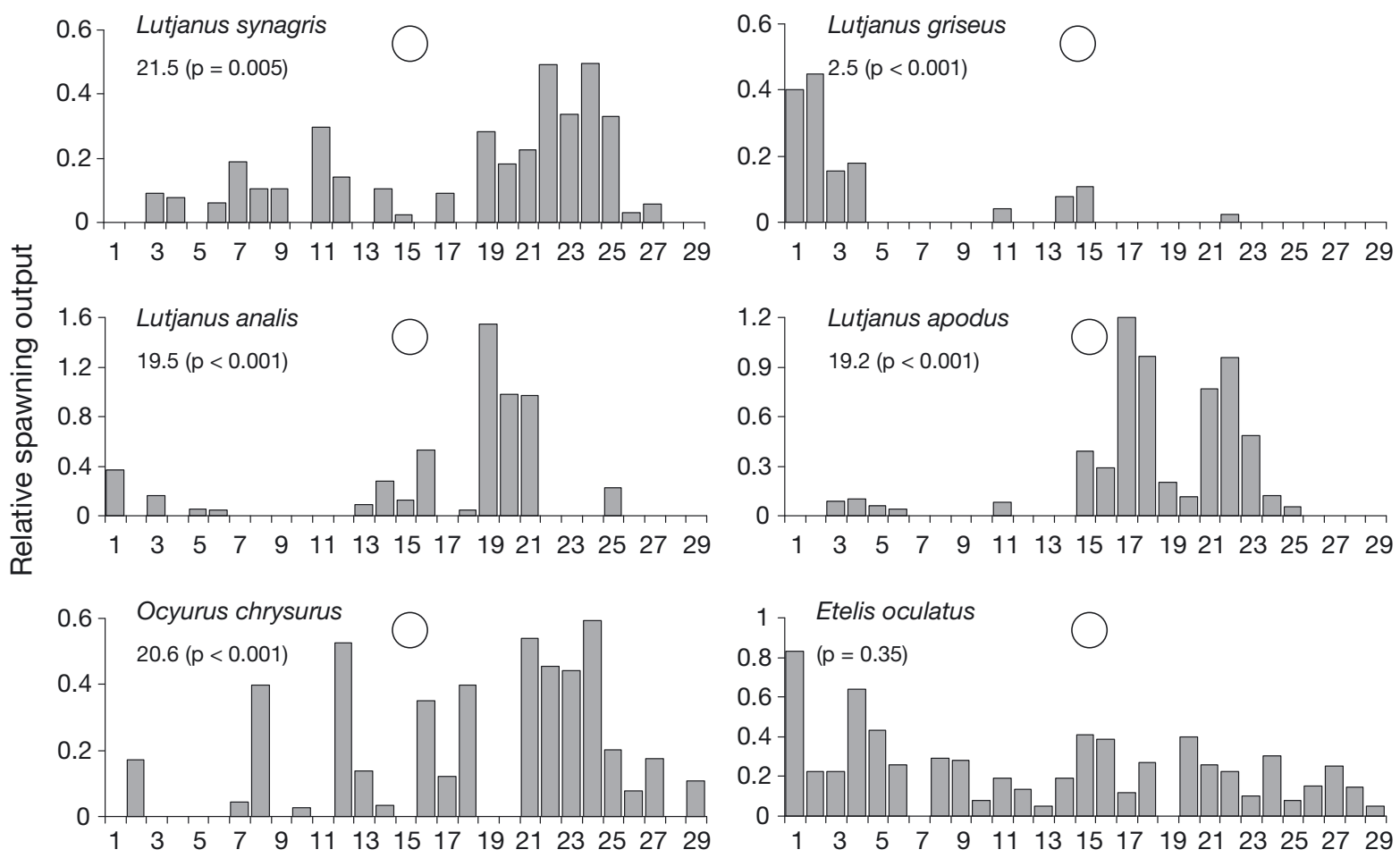

Lunar day

Fig. 4. Back-calculated successful spawning output by lunar day for 6 lutjanid species. Lunar Day 1 corresponds to the new moon and Day 15 to the full moon (circle). Numbers in graphs: lunar day about which the data were distributed; p-values in parentheses: Rayleigh tests

the 8 most abundant larval snapper species in the MOCNESS depth bins were all significantly nonuniform (Table 2) and similar among species: larvae were nearly absent from the surface, were most abundant in the upper $25 \mathrm{~m}$ of the water column, and decreased in abundance with depth (Fig. 2). Representative examples of this pattern were Lutjanus apodus and $L$. griseus, where $>80 \%$ of larvae caught were in the 0 to $25 \mathrm{~m}$ depth bin (Fig. 2). The only species that was most abundant deeper than 0 to $25 \mathrm{~m}$ (i.e. occurred in 25 to $50 \mathrm{~m}$ ) and did not have a uniform concentration across depth bins was Etelis oculatus (Table 2). Post-flexion larvae of this species along with Pristipomoides spp. were found significantly deeper in the water column than preflexion larvae ( $\mathrm{p}<0.05$; Fig. 5). L. apodus, which is associated with shallow coral reefs, displayed the opposite trend, where preflexion larvae were distributed deeper than were flexion or post-flexion larvae, although this depth difference was modest $(\sim 5 \mathrm{~m})$. The remaining species displayed a large amount of overlap in depth distributions of these stages.

Larvae of the deeper dwelling species, Rhomboplites aurorubens, Pristipomoides spp., and Lutjanus synagris, occurred more frequently in the western SOF, but concentrations (densities when present) were equivalent (Table 2), resulting in greater total abundances in the west for these species (Fig. 6). Larvae of L. analis and $L$. apodus, which are associated with shallow coral reefs, were both more abundant in the eastern SOF, but for different reasons. L. analis was more than twice as concentrated in the east, but its occurrence was even across the SOF, while L. apodus was even in larval concentration across the SOF but had higher occurrence values in the east. The remaining species were evenly distributed between east and west in both occurrence and concentration and the resulting total abundance patterns (Table 2, Fig. 6).

\section{Larval growth and mortality}

The otoliths of 387 snapper larvae of the 6 species chosen for analysis were removed and processed (Table 1). Fifty of these were not included in analyses largely due to damage caused to the fragile transverse section during processing. Highly significant $(p<0.01)$ positive relationships between SL and otolith radius, as well as between residuals of an otolith radius-at-age 


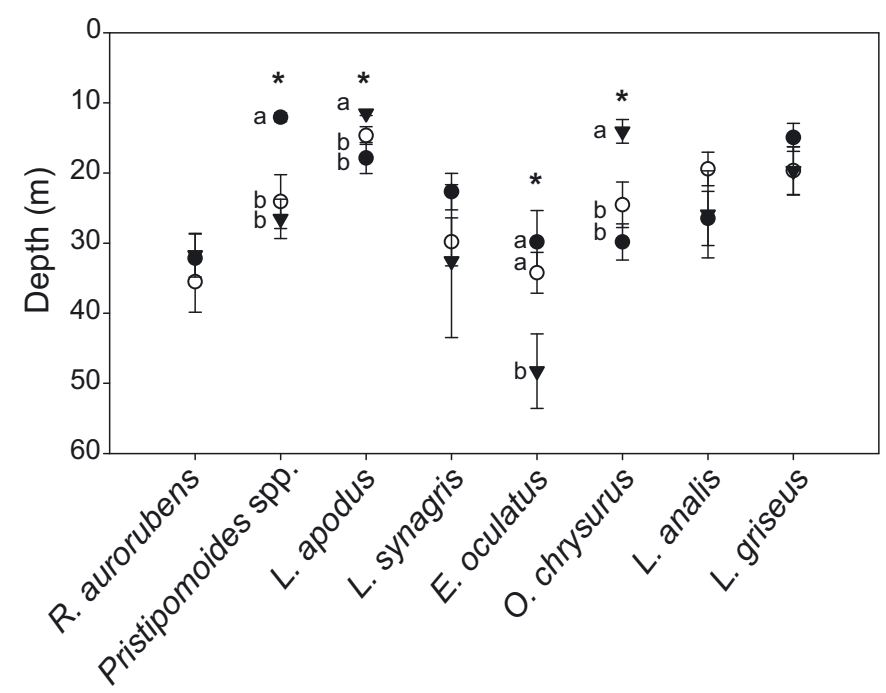

Fig. 5. The center of mass of preflexion $(\bullet)$, flexion (O) and postflexion $(\boldsymbol{\nabla})$ larvae of the 8 most abundant lutjanid taxa captured across the sampling transect in 2003 to 2004. Error bars: $\mathrm{SE}_{i}{ }^{*}$ statistically significant differences. Different letters indicate significant differences among stages regression and residuals of a SL-at-age regression, were identified for all species indicating that otolith increment data were appropriate to examine somatic larval growth.

Larval growth of Ocyurus chrysurus and Lutjanus synagris (otolith increment width) tended to be faster, resulting in larger sizes at age (otolith radius), on the western side of the SOF (Fig. 7). This difference was significant in 4 of 6 statistical tests performed on these otolith-based traits for these 2 species. L. analis and Etelis oculatus also exhibited this trend (Fig. 7), which was significantly different between regions in one test of individual otolith increment width (L. analis), or size at age (E. oculatus) (Table 3).

SL-at-age data fit with the Laird-Gomperz larval growth model revealed that overall growth curves of Ocyurus chrysurus, Lutjanus synagris, and L. analis were significantly different between east and west sides of the SOF (Table 3); larvae in the west exhibited a greater length at age than did those from the east. Instantaneous growth rates $(K)$ were similar among

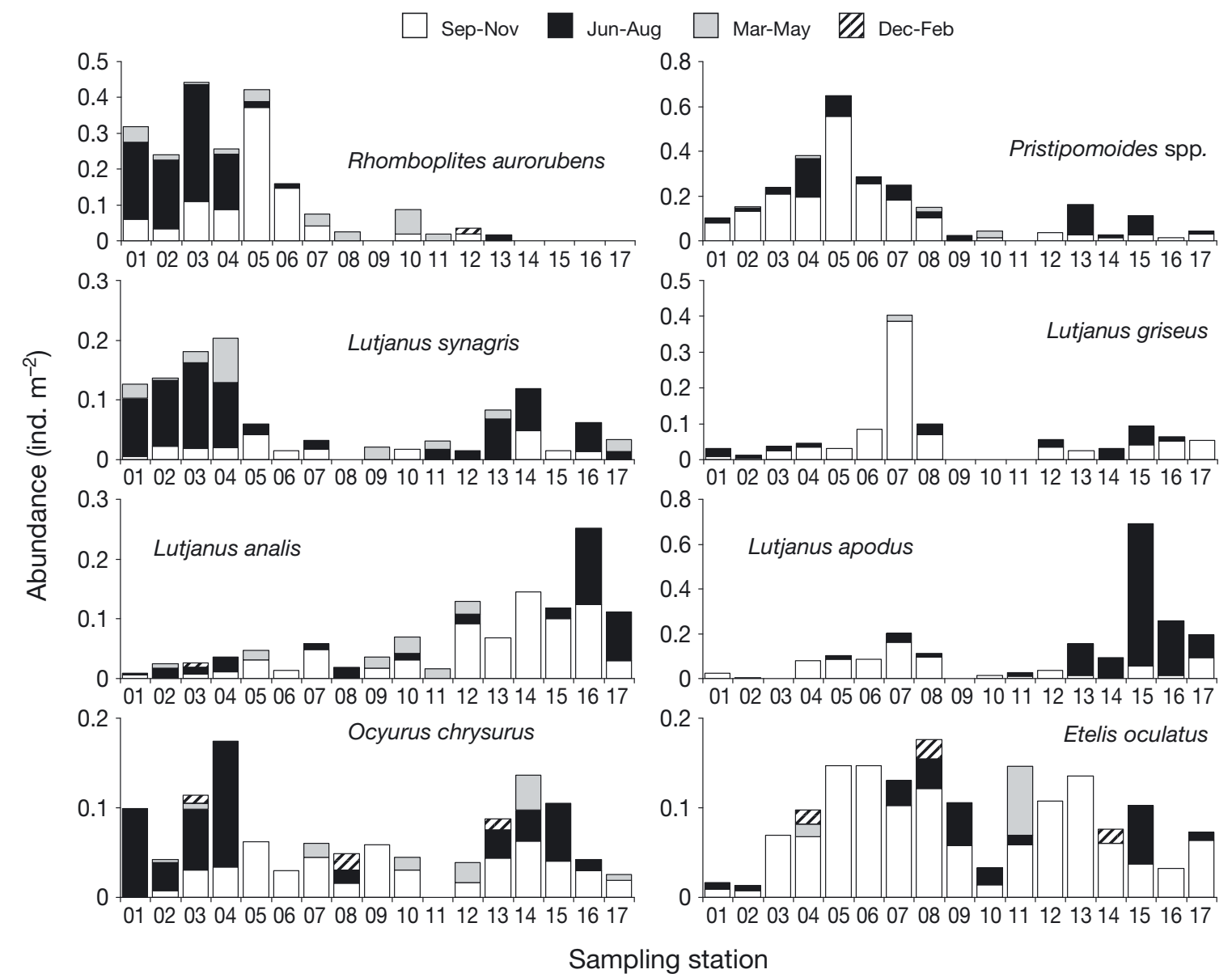

Fig. 6. Total larval abundance of the 8 most abundant lutjanid species collected from 17 stations across the Straits of Florida. Abundances were summed across years and separated into trimonthly seasonal periods to simplify illustration 
Growth
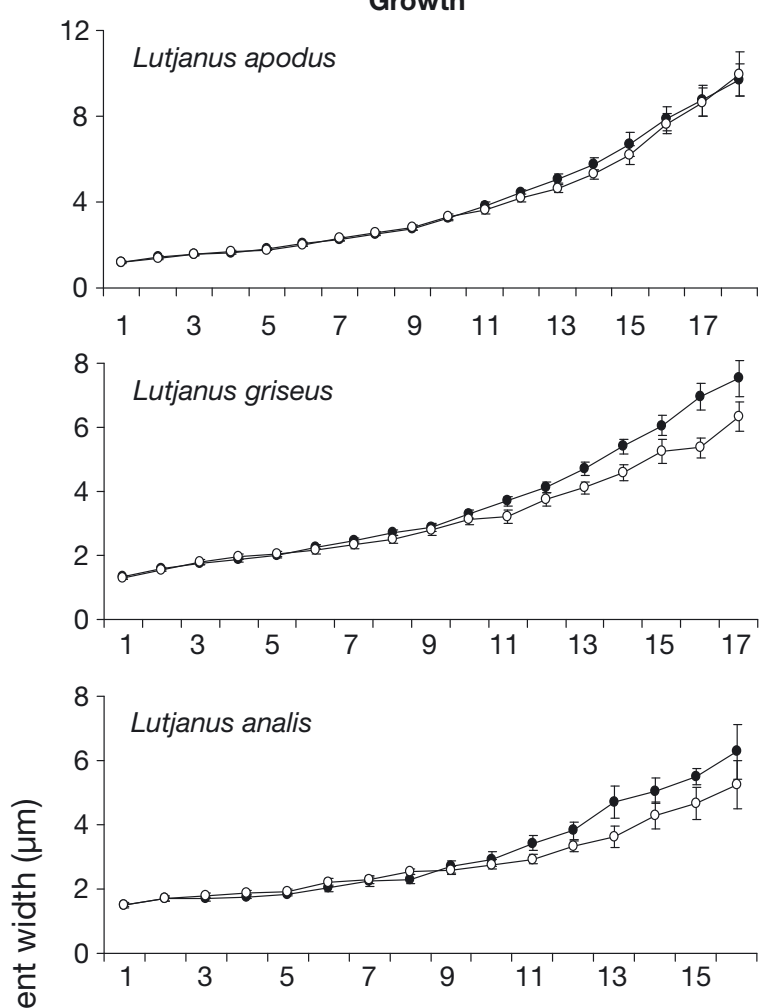

$\left.\begin{array}{ll}12 \\ \hline\end{array}\right]$ Etelis oculatus
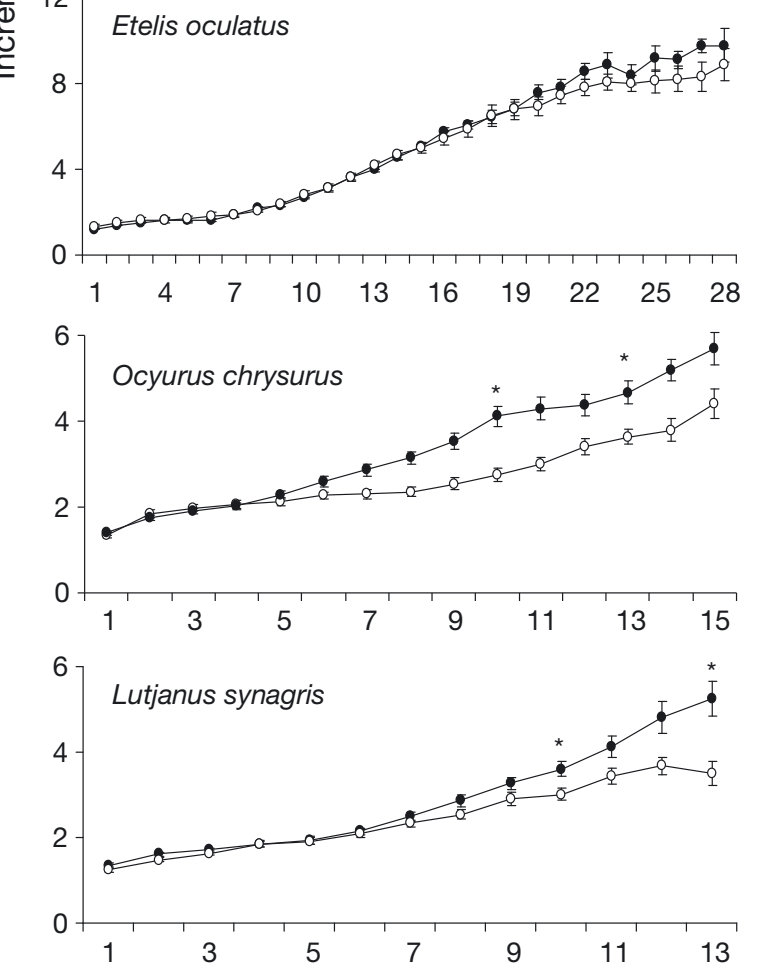

Size at age
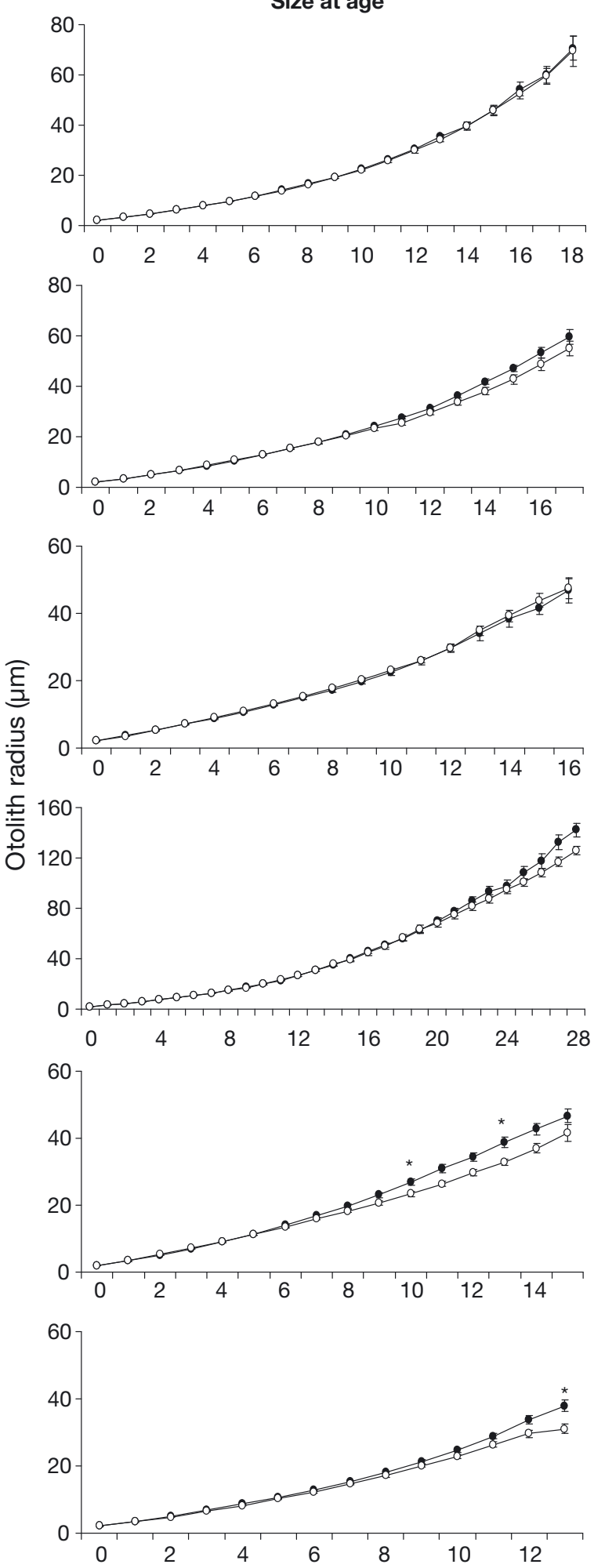

Increment number

Fig. 7. Mean larval otolith trajectories of 6 lutjanid species in terms of growth (individual otolith increment widths) and size at age (otolith radius at increment). $(\bullet, 0)$ Larvae captured on the western and eastern side of the Straits of Florida, respectively. Error bars: $\mathrm{SE}_{i}{ }^{*}$ statistically significant differences $(\mathrm{p}<0.05)$ 
Table 3. Probability values of statistical tests of larval growth (otolith increment width and SL-age curves) and size at age (otolith radius) between east and west sides of the Straits of Florida. ANCOVAs were used to test for differences between mean otolith increment widths, otolith radii at Days 10 and 13, and mean width and radius of the 3 most recent increments (last 3). Likelihood ratio tests were used to test for differences in SL-age curves. Bold: significant $(p<0.05)$; all significant test results indicated west growth > east growth

\begin{tabular}{|c|c|c|c|c|c|c|c|}
\hline \multirow[t]{2}{*}{ Species } & \multicolumn{3}{|c|}{$\begin{array}{l}\text { Growth (otolith increment } \\
\text { width in } \mu \mathrm{m} \text { ) at increment }\end{array}$} & \multicolumn{3}{|c|}{$\begin{array}{l}\text { Size (otolith radius } \\
\text { in } \mu \mathrm{m} \text { ) at increment }\end{array}$} & \multirow[t]{2}{*}{$\begin{array}{l}\text { SL-age } \\
\text { curve }\end{array}$} \\
\hline & 10 & 13 & last 3 & 10 & 13 & last 3 & \\
\hline Lutjanus synagris & 0.030 & 0.012 & $<0.001$ & 0.072 & 0.150 & $<0.001$ & 0.032 \\
\hline L. griseus & 0.532 & 0.072 & 0.084 & 0.465 & 0.361 & 0.357 & 0.127 \\
\hline L. analis & 0.214 & 0.390 & $<0.001$ & 0.703 & 0.853 & 0.143 & 0.010 \\
\hline L. apodus & 0.812 & 0.635 & 0.136 & 0.551 & 0.440 & 0.225 & 0.566 \\
\hline Ocyurus chrysurus & $<0.001$ & 0.071 & $<0.001$ & 0.014 & 0.176 & 0.041 & 0.001 \\
\hline Etelis oculatus & 0.588 & 0.415 & 0.425 & 0.929 & 0.025 & 0.436 & 0.113 \\
\hline
\end{tabular}

Table 4. Parameters of the Laird-Gompertz growth curves fit to the analyzed snapper species age-SL data. Separate east (E) and west (W) Straits of Florida curves were calculated where log-likelihood tests indicated significant differences between these regions. $L_{0}$ source: literature origin of the size-at-hatch parameter; $g_{0}$ : specific growth rate at hatch; $\alpha$ : rate of exponential decay of the specific growth rate. The instantaneous growth rate $K$ from a simple exponential growth curve $L_{t}=L_{0} \mathrm{e}^{K X_{t}}$ is also given $( \pm \mathrm{SE})$ to simplify comparison among species and with other studies. Mean: size-at-hatch data were not available and the average of the values identified for the other studied species was used

\begin{tabular}{|c|c|c|c|c|c|c|}
\hline Species & $g_{0}$ & $L_{0}$ & $\alpha$ & $\mathrm{r}^{2}$ & $K$ & $L_{0}$ source \\
\hline Lutjanus apodus & 0.032 & 2.26 & -0.037 & 0.82 & $0.047 \pm 0.004$ & Mean \\
\hline L. synagris $\mathrm{W}$ & 0.028 & 2.10 & -0.053 & 0.75 & $0.047 \pm 0.008$ & Laboratory reared larvae, Clarke et al. (1997) \\
\hline L. synagris E & 0.040 & 2.10 & -0.007 & 0.66 & $0.042 \pm 0.008$ & Laboratory reared larvae, Clarke et al. (1997) \\
\hline Etelis oculatus & 0.025 & 2.26 & -0.029 & 0.91 & $0.040 \pm 0.003$ & Mean \\
\hline Ocyurus chrysurus W & 0.044 & 2.23 & -0.010 & 0.64 & $0.048 \pm 0.007$ & $\begin{array}{l}\text { Laboratory reared larvae, Riley et al. (1995), } \\
\text { Clarke et al. (1997) }\end{array}$ \\
\hline Ocyurus chrysurus E & 0.025 & 2.23 & -0.052 & 0.72 & $0.041 \pm 0.009$ & $\begin{array}{l}\text { Laboratory reared larvae, Riley et al. (1995), } \\
\text { Clarke et al. (1997) }\end{array}$ \\
\hline L. analis W & 0.026 & 2.35 & -0.057 & 0.71 & $0.044 \pm 0.013$ & Laboratory reared larvae, Clarke et al. (1997) \\
\hline L. analis $\mathrm{E}$ & 0.017 & 2.35 & -0.079 & 0.74 & $0.039 \pm 0.012$ & Laboratory reared larvae, Clarke et al. (1997) \\
\hline L. griseus & 0.027 & 2.26 & -0.049 & 0.80 & $0.047 \pm 0.006$ & Mean \\
\hline
\end{tabular}

Table 5. Mortality rates $(Z, \pm \mathrm{SE})$ of larval lutjanids captured in the Straits of Florida from 2003 to 2004. $\mathrm{r}^{2}$ values are from the linear regressions fit to the descending half of the logtransformed age-frequency histogram. Rates were not significantly different between east and west portions of the Straits of Florida, so the data were pooled

\begin{tabular}{|lcc|}
\hline Species & $Z$ & $\mathrm{r}^{2}$ \\
\hline Lutjanus apodus & $-0.512 \pm 0.099$ & 0.82 \\
L. synagris & $-0.429 \pm 0.053$ & 0.93 \\
Etelis oculatus & $-0.133 \pm 0.023$ & 0.65 \\
Ocyurus chrysurus & $-0.319 \pm 0.091$ & 0.64 \\
L. analis & $-0.544 \pm 0.084$ & 0.91 \\
L. griseus & $-0.508 \pm 0.075$ & 0.92 \\
\hline
\end{tabular}

species and ranged from 0.039 to 0.048 (Table 4). Mortality rates $(Z)$ ranged from -0.544 to -0.133 (Table 5) and were not significantly different between the east and west SOF for any species.

\section{DISCUSSION}

All 8 snapper species had significant spatiotemporal distribution patterns with most snapper larvae occurring from July to September when water temperatures were warmest; they were rarely collected in surface waters and were most abundant in the upper $50 \mathrm{~m}$ towards the east or west sides of the SOF. Length and age ranges of snapper larvae were probably constrained by the sampling gear because small, young larvae probably slipped through the nets and large old larvae are increasingly able to avoid capture. Although we collected larvae as large as $24 \mathrm{~mm}$ SL, all large larvae (>13 mm SL) were eteline species. Larvae of lutjanine snappers associated with coral reefs typically settle to nearshore backreef environments at 13 to $25 \mathrm{~mm}$ SL (Lindeman 1997, Watson et al. 2002), and of these species no larvae $>10 \mathrm{~mm}$ SL were collected, suggesting that such larvae were able to avoid being captured 
or had already settled to juvenile habitat. In contrast, the presence of much larger eteline snappers in the samples suggests that there are swimming/sensory capability differences between these 2 groups. Eteline snappers may also have longer pelagic larval durations than do lutjanine snappers (Leis 1987), and our results are consistent with this suggestion (Etelis oculatus larvae captured up to age $36 \mathrm{~d}$ compared with $25 \mathrm{~d}$ in all other analyzed species). Thus, it is likely that the difference in age ranges between lutjanine and eteline larvae is the result of both settlement schedules and larval performance; though, no performance or settlement data for eteline snappers are currently available to support or refute this hypothesis.

Seasonal larval abundance was similar among species and the onset of spawning is probably cued by water temperature (above $\sim 27^{\circ} \mathrm{C}$ ) and/or photoperiod ( 13 h daylight), manipulations of which have been used successfully to initiate spawning of captive Ocyurus chrysurus $\left(24^{\circ} \mathrm{C}\right.$ and $15 \mathrm{~h}$ daylight, Turano et al. 2000). Despite between-year variability and presence of snapper larvae in most months, temporal distributions of larval abundance, occurrence, and concentration all point to peaks in spawning activity in July to September, consistent with existing literature and the subtropical area sampled (Thresher 1984, Grimes 1987, Leis 1987).

Of the 6 species for which the spawning date could be back-calculated, 4 exhibited peak spawning centered within a $4 \mathrm{~d}$ period around the third quarter moon (Lunar Days 19 to 22), which is similar to when spawning aggregations of several snapper species have been observed in Florida (Domeier \& Colin 1997, Burton et al. 2005) and Belize (Heyman \& Kjerfve 2008). Although slightly different, the new moon peak in Lutjanus griseus also agrees with previous studies of this species (Domeier et al. 1996, Tzeng et al. 2003, Denit \& Sponaugle 2004). Most literature identifies some form of lunar periodicity in snapper spawning (but see Allman 1999), yet the specific patterns identified vary (reviewed in Thresher 1984, Grimes 1987, Tzeng et al. 2003, Denit \& Sponaugle 2004). Direct observations of spawning are rare or absent for most snapper species (but see Carter \& Perrine 1994, Heyman \& Kjerfve 2008); thus, most lunar patterns have been identified through back-calculation of spawning dates from otolith analysis of juveniles and larvae. Such data represent successful spawning, or spawning of individuals that have survived and grown to the ontogenetic stage sampled, and do not preclude the possibility of less successful spawning at other times of the lunar month. Etelis oculatus was unique in having no lunar spawning pattern, and along with Pristipomoides spp., possessing several other attributes different from lutjanine snappers. These taxa are the only representatives of the subfamily Etelinae in the western central Atlantic and adults are among the deepest dwelling of all snappers. The deep adult distribution of E. oculatus may have contributed to the lack of a lunar cyclic spawning pattern in this species, as such environments may not be significantly affected by lunar or tidal cycles.

The vertical distribution of all snapper larvae (scarce at the surface and most abundant in the upper $50 \mathrm{~m}$ ) is shared by many reef fish families (reviewed in Leis 1991, Cowen 2002) and probably reflects larval behavior in response to prey and predator distributions (reviewed in Cowen 2002). Despite the frequently observed pattern that larvae of pelagic reef fishes, including snappers, exhibit more structured vertical distributions during the day than at night (reviewed in Leis 1987, 1991), 2 other ichthyoplankton studies in the SOF found similar patterns to ours, with no difference in the vertical distribution of lutjanids between night and day (Cha et al. 1994). The deeper dwelling taxa, Rhomboplites aurorubens, Pristipomoides spp., and Etelis oculatus, all exhibited somewhat deeper depth distributions (especially E. oculatus) and all moved deeper in the water column with development. These differences in depth distributions and changes with ontongeny are consistent with relative differences in depth distributions for adults of the species.

The sampling transect across the SOF spanned several different environments including continental shelf, shelf slope and oceanic waters. The low larval abundance exhibited by most examined snapper species at middle stations (slope and oceanic waters) relative to those closer to Florida or the Great Bahama Bank (shelf waters) probably reflects the restriction of adults to shallower eastern and western sides of the SOF. Reduced cross-SOF mixing in the strong unidirectional FC would result in retention of eggs and larvae close to the side where they originated. In contrast, larvae of Etelis oculatus, although statistically evenly distributed across the SOF, tended to be more abundant at middle stations than were those on the periphery of the SOF. Similar results have been found elsewhere for other eteline snappers (Leis 1987) and probably reflect their deep adult distribution. Although species-specific variability in cross-SOF distributions of the 7 remaining species could have been caused by spatial differences in growth and mortality rates, different patterns of abundance exhibited by closely related species make this explanation unlikely. More likely, these patterns are also reflective of upstream adult populations. Adult Pristipomoides aquilonaris are not reported in the areas upstream of the eastern SOF (northern coast of Cuba and Bahamas, Anderson 2002), while adults of the other 2 species in this genus ( $P$. macrophthalmus and $P$. freemani) are 
not reported in areas upstream of the western SOF (Florida Keys, Gulf of Mexico, and Yucatan Peninsula). Most of our Pristipomoides spp. larvae may therefore be $P$. aquilonaris and reflect adult distributions. Adults of both Rhomboplites aurorubens and Lutjanus synagris inhabit the deep shelf (40 to $100 \mathrm{~m}$ ), and the larvae of both were more abundant in the western SOF. In contrast, $L$. apodus and $L$. analis are restricted to nearshore backreef and shallow coral reef habitats (juveniles, <10 m depth; adults, <70 m depth), and their larvae were more abundant in the eastern SOF. Although regional adult stock assessments are not available, the areas upstream of the eastern side of the SOF (Yucatan Peninsula, Cuba, Cay Sal Bank) contain ample shallow coral reefs. The Florida Keys and Dry Tortugas also contain numerous coral reefs, but areas farther upstream of the western side of the SOF (Florida's west shelf) are devoid of coral reefs and probably the fishes associated with them. The idea of horizontal distributions of larvae reflecting adult distributions is not novel for snappers and was suggested by Powles (1977). Our data are consistent with this concept, suggesting that larval distributions mirror adult distributions in both horizontal and vertical dimensions.

Instantaneous larval growth rates $(K)$ were similar among species and regions in this study, but were markedly lower than larval growth rates of Atlantic blue marlin Makaira nigricans ( $K=0.110$; age range: 1 to $20 \mathrm{~d}$ ) and sailfish Istiophorus platypterus ( $K=0.134$; age range: 2 to $18 \mathrm{~d}$ ) from the same ichthyoplankton samples (Sponaugle et al. 2010), or Rhomboplites aurorubens larvae ( $K$ range: 0.087 to 0.115 ; age range: 5 to $14 \mathrm{~d}$ ) collected in the Gulf of Mexico (Comyns et al. 2003). However, these differences are probably species-specific as growth rates presented here were similar to larval growth rates of laboratory-reared larvae of Lutjanus analis ( $K=0.071$, Clarke et al. 1997), L. synagris $(K=0.064$, Clarke et al. 1997) and Ocyurus chrysurus $(K=0.036$, Riley et al. $1995 ; K=0.0618$, Clarke et al. 1997) that were held at temperatures of 27.0 to $28.5^{\circ} \mathrm{C}$, similar to those our larvae experienced.

Despite differences in horizontal distribution, 4 of 6 examined snapper species exhibited a trend of enhanced larval growth on the western side of the SOF which was significant in at least one statistical test (of increment width, otolith radius, last $3 \mathrm{~d}$ growth before capture or SL-age growth curve). This pattern was significant in 5 statistical tests for Ocyurus chrysurus and Lutjanus synagris. Although spatial differences in growth such as these may be obscured by active or passive mixing of larvae between east and west SOF, significant differences in the $3 \mathrm{~d}$ of growth before capture in these 3 species coupled with the strong unidirectional flow of the FC reduce the likelihood of this scenario. Further, cross-SOF mixing of larvae would serve to homogenize growth rates, making our results conservative. The observed pattern may have been caused by differences in water temperature, food availability, intrinsic growth rates, selective mortality, or density-dependence. That species more abundant in the west (L. synagris), more abundant in the east ( $L$. analis) and equally abundant in the east and west ( $O$. chrysurus) all exhibited higher growth in the west, precludes density-dependent growth as a dominant causative factor. Further, it has been suggested that the diffuse concentrations of reef fish larvae in this area are insufficient to deplete prey to an extent that density dependence could operate (J. K. Llopiz \& R. K. Cowen unpubl. data). The possibility that 2 distinct populations with intrinsically different growth rates are supplying eggs and larvae to the east and west SOF is unlikely because molecular evidence suggests substantial gene flow in pelagic spawning Caribbean fish populations with moderate pelagic larval durations (Purcell et al. 2006, Shulzitski et al. 2009). Although temperature can affect larval growth rates, its effect on otolith growth rate and size at age were never significant in east-west comparisons. In addition, temperature variability in the upper $50 \mathrm{~m}$ of the water column between east and west SOF was low $\left(\sim 2^{\circ} \mathrm{C}\right)$ during the truncated spawning season of the study species and tended to be $\sim 0.2^{\circ} \mathrm{C}$ lower in the west during the $2 \mathrm{yr}$ study (west: $26.97 \pm 0.08^{\circ} \mathrm{C}_{\text {; }}$ east: $27.24 \pm 0.08^{\circ} \mathrm{C}$ ), a difference that would have caused reduced, rather than increased larval growth. Higher mortality rates in conjunction with selection for slowgrowing larvae in the west may have contributed to faster growth rates; however, mortality rates were equivalent between regions, precluding this scenario.

Growth of bluehead wrasse Thalassoma bifasciatum larvae and small (<9 mm SL) zooplanktivorous Makaira nigricans larvae was also higher in the western SOF (Sponaugle et al. 2009, 2010). Faster growth was correlated with fuller guts and higher abundances of primary prey items (Farranula, harpacticoid and Oncaea copepods) in the west SOF for T. bifasciatum (Sponaugle et al. 2009) and with a higher proportion of Farranula relative to Evadne copepods in M. nigricans (Sponaugle et al. 2010). Consistent with the spatial pattern of primary and secondary production reported for this area (Hitchcock et al. 2005, Llopiz 2008), appendicularians, the major prey of Lutjaninae snappers, also are more abundant in the western SOF (Llopiz et al. 2010). Thus, the most likely cause of the observed pattern of higher growth in snapper larvae in the western SOF is the higher western abundance of this major prey.

Larval mortality rates presented here were apparent rates that were biased by net avoidance and advection, but are well within the range found for many other 
species of marine fish larvae (Houde 1989, Morse 1989). Although the larval mortality rate of Etelis oculatus was lower than for the other snapper species examined, it was similar to that of another deeperdwelling species, Rhomboplites aurorubens, reported from the Gulf of Mexico ( $Z$ range: 0.18 to 0.29, Comyns et al. 2003). Alternatively, the lower larval mortality rate in this species may have resulted from the older age range ( 20 to $35 \mathrm{~d}$ ) used to calculate $Z$ in this species, as larval mortality is thought to decline with age and size (Houde 2002). Also consistent with a decline in mortality with ontogeny, larval mortality rates from the present study were higher than juvenile mortality rates of Lutjanus synagris ( $Z$ range: 0.097 to $0.165, \mathrm{Mi}-$ kulas \& Rooker 2008), L. griseus ( $Z$ range: 0.14 to 0.43 , Allman \& Grimes 2002) and Ocyurus chrysurus (Watson et al. 2002).

This study represents the first detailed ELH information for several ecologically and economically important snapper species. Consistent spatial differences in larval growth rates such as those identified here may have important implications for larval survival, recruitment, and ultimately adult populations of reef fishes. Not only does larval growth influence survivorship of larvae and subsequent recruitment magnitude (reviewed in Houde 2002), but its effects can carry over and influence juvenile survival (e.g. Gagliano et al. 2007) and effective population connectivity. Dispersal kernels, which define the probability that a larva will arrive at settlement habitat over a certain distance, are a function of larval transport, survival and time spent in the plankton (Pineda et al. 2007, Cowen \& Sponaugle 2009). The consistent spatial differences in larval growth rates shown in the present study could alter dispersal kernels of the same species sourced from different areas, with larvae on the west side of the SOF reaching competency to settle sooner and, thus, having smaller overall dispersal kernels. Understanding population connectivity (dispersal kernels) of ecologically and economically important fishes like snappers is essential to effective spatial management (Fogarty \& Botsford 2007). Thus, the species-specific spatiotemporal patterns of larval abundance as well as consistent growth patterns described in this study are directly applicable to management of snapper species and are key elements in parameterizing complex biophysical models, thereby refining our understanding of population connectivity and ensuring sustainability of marine resources in the future (Cowen \& Sponaugle 2009). In addition, this study has provided the first glimpse into the larval life of snappers on a species-by-species basis. This resolution, in conjunction with the consistent sampling design, provides insights into relative abundances of upstream adult populations that are difficult to survey.
Acknowledgements. This study was supported by a National Science Foundation grant (OCE 0136132) to R. K. Cowen, S. Sponaugle, S. Smith, K. Leaman, D. Olson and J. Serafy. R. K. Cowen, D. Richardson, J. Llopiz, C. Guigand, P. Lane, A. Shiroza, K. Leaman, P. Vertes, K. Huebert, and S. Smith participated in shipboard cruises. All samples were collected under University of Miami Animal Care and Use Committee permit nos. 02063 and 05134. Sample sorting was conducted by L. Gundlach, A. Exum, and S. Trbovich, and family level identifications were made by J. Llopiz and D. Richardson. Assistance with molecular identification of larvae was provided by D. Crawford, J. VanWye, A. Miake, M. Everett, T. LabergeMcDonald, and L. Williams. A previous version of the manuscript was improved upon thanks to comments from R. K. Cowen, A. Acosta, and D. Lirman.

\section{LITERATURE CITED}

Ahrenholz DW (2000) Periodicity of growth increment formation in otoliths of juvenile gray snapper (Lutjanus griseus) and lane snapper (Lutjanus synagris). J Elisha Mitchell Sci Soc 116:251-259

Allman RJ (1999) The temporal and spatial dynamics of spawning, settlement, and growth of gray snapper (Lutjanus griseus) determined using otolith micro-structure. MS thesis, Florida State University, Tallahassee, FL

Allman RJ, Grimes CB (2002) Temporal and spatial dynamics of spawning, settlement, and growth of gray snapper (Lutjanus griseus) from the West Florida shelf as determined from otolith microstructures. Fish Bull 100:391-403

Anderson WD (2003) Lutjanidae. In: Carpenter KE (ed) The living marine resources of the western central Atlantic, Vol 3. Bony fishes. Part 2 (Opistognathidae to Molidae). FAO Species Identification Guide for Fishery Purposes and American Society of Ichthyologist and Herpetologists Special Publication 5. FAO, Rome, p 1479-1504

Burton ML, Brennan KJ, Munoz RC, Parker RO (2005) Preliminary evidence of increased spawning aggregations of mutton snapper (Lutjanus analis) at Riley's Hump two years after establishment of the Tortugas South Ecological Reserve. Fish Bull 103:404-410

Carter J, Perrine D (1994) A spawning aggregation of dog snapper, Lutjanus jocu (Pisces, Lutjanidae) in Belize, Central America. Bull Mar Sci 55:228-234

Cha SS, McGowan MF, Richards WJ (1994) Vertical distribution of fish larvae off the Florida Keys, 26 May-5 June 1989. Bull Mar Sci 54:828-842

Clarke ME, Domeier ML, Laroche WA (1997) Development of larvae and juveniles of the mutton snapper (Lutjanus analis), lane snapper (Lutjanus synagris) and yellowtail snapper (Lutjanus chrysurus). Bull Mar Sci 61:511-537

Comyns BH, Shaw RF, Lyczkowski-Shultz J (2003) Smallscale spatial and temporal variability in growth and mortality of fish larvae in the subtropical northcentral Gulf of Mexico: implications for assessing recruitment success. Fish Bull 101:10-21

Cowen RK (2002) Larval dispersal and retention and consequences for population connectivity. In: Sale PF (ed) Coral reef fishes: dynamics and diversity in a complex ecosystem. Academic Press, New York, NY, p 149-170

Cowen RK, Sponaugle S (2009) Larval dispersal and marine population connectivity. Annu Rev Mar Sci 1:443-466

> Denit K, Sponaugle S (2004) Growth variation, settlement, and spawning of gray snapper across a latitudinal gradient. Trans Am Fish Soc 133:1339-1355

Domeier ML, Colin PL (1997) Tropical reef fish spawning 
aggregations: defined and reviewed. Bull Mar Sci 60: 698-726

Domeier ML, Koenig C, Coleman F (1996) Reproductive biology of gray snapper (Lutjanus griseus) with notes on spawning for other western Atlantic snappers (Lutjanidae). In: Arreguin-Sanchez F, Munro JL, Balgos MC, Pauly D (eds) ICLARM (International Center for Living Aquatic Resources Management) Conf Proc 48, Makati City, Phillipines, p 189-201

Drass DM, Bootes KL, Lyczkowski-Shultz J, Comyns BH, Holt GJ, Riley CM, Phelps RP (2000) Larval development of red snapper, Lutjanus campechanus, and comparisons with co-occurring snapper species. Fish Bull 98:507-527

Fogarty MJ, Botsford LW (2007) Population connectivity and spatial management of marine fisheries. Oceanography 20:112-123

Gagliano M, McCormick MI, Meekan MG (2007) Survival against the odds: ontogenetic changes in selective pressure mediate growth-mortality trade-offs in a marine fish. Proc Biol Sci 274:1575-1582

Grimes CB (1987) Reproductive biology of the Lutjanidae: a review. In: Polovina JJ, Ralston S (eds) Tropical snappers and groupers: biology and fisheries management. Westview Press, Boulder, CO, p 239-294

Guigand CM, Cowen RK, Llopiz JK, Richardson DE (2005) A coupled asymmetrical multiple opening closing net with environmental sampling system. Mar Technol Soc J 39: $22-24$

Hare JA, Cowen RK (1995) Effect of age, growth rate and ontogeny on the relationship between otolith and somatic size in bluefish, Pomatomus saltatrix, and the implications for the back-calculation of size in the early life history stages of fishes. Can J Fish Aquat Sci 52:1909-1922

Heyman WD, Kjerfve B (2008) Characterization of transient multi-species reef fish spawning aggregations at Gladden Spit, Belize. Bull Mar Sci 83:531-551

Hitchcock GL, Lee TN, Ortner PB, Cummings S, Kelble C, Williams E (2005) Property fields in a Tortugas eddy in the southern Straits of Florida. Deep-Sea Res 1:2195-2213

Houde ED (1987) Fish early life dynamics and recruitment variability. Am Fish Soc Symp 2:17-29

Houde ED (1989) Comparative growth, mortality, and energetics of marine fish larvae: temperature and implied latitudinal effects. Fish Bull 87:471-495

Houde ED (2002) Mortality. In: Fuiman LA, Werner RG (eds) Fishery science: the unique contributions of early life stages. Blackwell Science, Malden, MA, p 64-87

Houde ED, Leak JC, Dowd CE, Berkeley SA, Richards WJ (1979) Ichthyoplankton abundance and diversity in the eastern Gulf of Mexico. NTIS No PB299-839/AS. Report for the US Department of the Interior, Bureau of Land Management, Gulf of Mexico OCS Office, New Orleans, LA

Kimura DK (1980) Likelihood methods for the von Bertalanffy growth curve. Fish Bull 77:765-766

Leis JM (1987) Review of the early life history of tropical groupers (Serranidae) and snappers (Lutjanidae). In: Polovina JJ, Ralston S (eds) Tropical snappers and groupers: biology and fisheries management. Westview Press, Boulder, CO, p 189-237

Leis JM (1991) The pelagic stage of reef fishes: the larval biology of coral reef fishes. In: Sale PF (ed) The ecology of fishes on coral reefs. Academic Press, New York, NY, p $183-230$

Lindeman KC (1997) Development of grunts and snappers of Southeast Florida: cross-shelf distributions and effects of beach management alternatives. PhD dissertation, University of Miami, FL
Lindeman KC, Richards WJ, Lyczkowski-Shultz J, Drass DM and others (2006) Lutjanidae: snappers. In: Richards WJ (ed) Early stages of Atlantic fishes: an identification guide for the western central North Atlantic, Vol II. Taylor \& Francis, New York, NY, p 1549-1585

Llopiz JK (2008) The trophic ecologies of larval billfishes, tunas and coral reef fishes in the Straits of Florida: piscivory, selectivity, and niche separation. PhD dissertation, University of Miami, FL

Llopiz JK, Cowen RK (2009) Variability in the trophic role of coral reef fish larvae in the oceanic plankton. Mar Ecol Prog Ser 381:259-272

Llopiz JK, Richardson DE, Shiroza A, Smith SL, Cowen RK ((2010) Distinctions in the diets and distributions of larval tunas and the important role of appendicularians. Limnol Oceanogr 55(3):983-996

Lyczkowski-Shultz J, Steen JPJ (1991) Diel vertical distribution of red drum Sciaenops ocellatus larvae in the northcentral Gulf of Mexico. Fish Bull 89:631-641

> Mikulas JJ Jr, Rooker JR (2008) Habitat use, growth, and mortality of post-settlement lane snapper (Lutjanus synagris) on natural banks in the northwestern Gulf of Mexico. Fish Res 93:77-84

Morse WW (1989) Catchability, growth, and mortality of larval fishes. Fish Bull 87:417-446

Moura RL, Lindeman KC (2007) A new species of snapper (Perciformes: Lutjanidae) from Brazil, with comments on the distribution of Lutjanus griseus and L. apodus. Zootaxa 1422:31-43

Nelson JS (2006) Fishes of the world, 4th edn. John Wiley, New York, NY

> Nielsen R, Munk P (2004) Growth pattern and growth dependent mortality of larval and pelagic juvenile North Sea cod Gadus morhua. Mar Ecol Prog Ser 278:261-270

Pineda J, Hare JA, Sponaugle S (2007) Larval transport and dispersal in the coastal ocean and consequences for population connectivity. Oceanography 20:22-39

Powles H (1977) Larval distributions and recruitment hypotheses for snappers and groupers of the South Atlantic Bight. Proc Annu Conf SW Assoc Fish Wildl Agencies 31: 362-371

Purcell JFH, Cowen RK, Hughes CR, Williams DA (2006) Weak genetic structure indicates strong dispersal limits: a tale of two coral reef fish. Proc Biol Sci 273:1483-1490

Ratnasingham S, Hebert PDN (2007) BOLD: The barcode of life data system (www.barcodinglife.org). Mol Ecol Notes 7:355-364

> Richardson DE, Vanwye JD, Exum AM, Cowen RK, Crawford DL (2007) High-throughput species identification: from DNA isolation to bioinformatics. Mol Ecol Notes 7: 199-207

> Richardson DE, Cowen RK, Prince ED, Sponaugle S (2009) Importance of the Straits of Florida spawning ground to Atlantic sailfish (Istiophorus platypterus) and blue marlin (Makaira nigricans). Fish Oceanogr 18:402-418

Richardson DE, Llopiz JK, Guigand CM, Cowen RK (2010) Larval assemblages of large and medium sized pelagic species in the Straits of Florida. Prog Oceanogr 86:8-20

Riley CM, Holt GJ, Arnold CR (1995) Growth and morphology of larval and juvenile captive bred yellowtail snapper, Ocyurus chrysurus. Fish Bull 93:179-185

Serafy JE, Cowen RK, Paris CB, Capo TR, Luthy SA (2003) Evidence of blue marlin, Makaira nigricans, spawning in the vicinity of Exuma Sound, Bahamas. Mar Freshw Res 54:299-306

Serafy JE, Valle M, Faunce CH, Luo J (2007) Species-specific patterns of fish abundance and size along a subtropical 
mangrove shoreline: an application of the delta approach. Bull Mar Sci 80:609-623

Shulzitski K, McCartney MA, Burton ML (2009) Population connectivity among Dry Tortugas, Florida, and Caribbean populations of mutton snapper (Lutjanus analis), inferred from multiple microsatellite loci. Fish Bull 107:501-509

Sponaugle S (2009) Daily otolith increments in the early stages of tropical fish. In: Green BS, Mapstone BD, Carlos G, Begg GA (eds) Tropical fish otoliths: information for assessment, management and ecology. Springer, New York, NY, p 93-132

Sponaugle S, Llopiz JK, Havel LN, Rankin TL (2009) Spatial variation in larval growth and gut fullness in a coral reef fish. Mar Ecol Prog Ser 383:239-249

Sponaugle S, Walter KD, Denit KL, Llopiz JK, Cowen RK (2010) Variation in pelagic larval growth of Atlantic billfishes: the role of prey composition and selective mortaltiy. Mar Biol 157:839-849

Thresher RE (1984) Reproduction in reef fishes. T.F.H. Publications, Neptune City, NJ

Editorial responsibility: Matthias Seaman, Oldendorf/Luhe, Germany
Turano MJ, Davis DA, Arnold CR (2000) Observations and techniques for maturation, spawning, and larval rearing of the yellowtail snapper Ocyurus chrysurus. J World Aquac Soc 31:59-68

Tzeng MW, Hare JA, Lindquist DG (2003) Ingress of transformation stage gray snapper, Lutjanus griseus (Pisces: Lutjanidae) through Beaufort Inlet, North Carolina. Bull Mar Sci 72:891-908

Ward RD, Zemlak TS, Innes BH, Last PR, Hebert PDN (2005) DNA barcoding Australia's fish species. Philos Trans R Soc Lond B Biol Sci 360:1847-1857

Watanabe WO, Ellis EP, Ellis SC, Chaves J and others (1998) Artificial propagation of mutton snapper Lutjanus analis, a new candidate marine fish species for aquaculture. J World Aquac Soc 29:176-187

> Watson M, Munro JL, Gell FR (2002) Settlement, movement and early juvenile mortality of the yellowtail snapper Ocyurus chrysurus. Mar Ecol Prog Ser 237:247-256

Zar JH (1999) Biostatistical analysis, 4th edn. Prentice Hall, Upper Saddle River, NJ

Submitted: November 6, 2009; Accepted: April 20, 2010

Proofs received from author(s): July 7, 2010 